\begin{tabular}{l|ll}
\hline DE & DE GRUYTER & $\begin{array}{c}\text { HUNGARIAN JOURNAL OF } \\
\text { INDUSTRY AND CHEMISTRY } \\
\text { Vol. 45(2) pp. 23-27 (2017) } \\
\text { hjic.mk.uni-pannon.hu } \\
\text { DOl: 10.1515/hjic-2017-0016 }\end{array}$
\end{tabular}

\title{
THE EFFECT OF ADVANCED OXIDATION PRE-TREATMENT ON THE MEMBRANE FILTRATION PARAMETERS OF DAIRY WASTEWATER
}

\author{
MIHÁly ZAKAR, ${ }^{1,2}$ ILDIKÓ KOVÁCS, ${ }^{1}$ PÉTER MUHI, ${ }^{1}$ ERIKA HANCZNÉ LAKATOS, ${ }^{2}$ \\ GÁBOR KESZTHELYI-SZABÓ, ${ }^{1}$ ZSUZSANNA LÁSZLOO ${ }^{1, *}$ \\ ${ }^{1}$ Institute of Mechanical and Process Engineering, Faculty of Engineering, University of Szeged, \\ Moszkvai krt. 9, Szeged, 6724, HUNGARY \\ 2 Institute of Food Sciences, Széchenyi István University, Lucsony u. 15-17, Mosonmagyaróvár, \\ 9200, HUNGARY
}

\begin{abstract}
The dairy industry generates wastewater characterised by high levels of biological and chemical oxygen demands representative of their high degree of organic content; mainly carbohydrates, proteins and fats that originate from milk. Several investigations have been conducted into the reuse of dairy wastewater, e.g. membrane processes are a promising method to treat such wastewater. Earlier works have proven that with membrane filtration an appropriate degree of retention can be achieved and the permeate can be reused. However, membrane fouling is a limiting factor in these processes. Advanced oxidation processes (AOPs) are widely used in the fields of water and wastewater treatments and are known for their capability to mineralise a wide range of organic compounds. AOPs also exhibit some other effects on the filtration process, e.g. the microflocculation effect of ozone may play a significant role in increasing the elimination efficiency and causing a decreased level of irreversible fouling. By comparing ozone and Fenton pre-treatment (FPT) processes it can be shown that the fouling propensity of pre-treated pollutants does not depend on the pre-treatment method, while FPT was proven to be more efficient in improving the level of flux.
\end{abstract}

Keywords: ultrafiltration, ozone pre-treatment, Fenton-reaction, fouling resistances, dairy wastewater

\section{Introduction}

The dairy industry is considered to be the largest source of food-processing wastewater in many countries. Dairy wastewater exhibits high degrees of biological oxygen demand (BOD) and chemical oxygen demand (COD); contains high levels of dissolved or suspended solids including fats, oils and grease; as well as nutrients such as ammonium ions or phosphates. Therefore, proper attention must be paid to them before disposal [1] There are several research projects that aim to identify possibilities of reusing or recycling dairy wastewater [29]. Membrane treatment of dairy wastewater with the aim of water reuse could simultaneously lower the total water consumption and effluent production of dairy plants, as the purified water produced could be reused in a dairy plant to heat or cool water. Besides additional advantages, e.g. a high degree of separation efficiency in the absence of chemical changes and low levels of energy intensity, membrane filtration also has drawbacks, namely compounds in dairy wastewater that contain protein were found to be significant foulants in terms of existing membrane materials [10-12].
The combination of membrane separation and pretreatment with advanced oxidation processes (AOPs: using ozone, hydrogen peroxide, UV light, or a combination of these) opens up new opportunities, since the ozone and the resulting oxidizing radicals (mainly hydroxyl radicals) efficiently change the characteristics of the colloidal particles or oxidizing compounds, which cause membrane fouling [13]. Earlier studies have shown that the microflocculation effect of ozone may play a significant role in increasing the elimination efficiency and may decrease the extent of membrane fouling and increase the degree of gel formation. In addition, AOPs can be used as a pre-treatment stage before a biological step in order to increase the biodegradability of the recalcitrant compounds and thus lower the toxicity of the wastewaters [13-14].

According to economic evaluation studies, the Fenton process is more economical than ozone pretreatment [15]. However, there is little data concerning its effect on membrane filtration parameters. The aim of the present work was to investigate and compare the effect of ozone pre-treatment and the Fenton's reaction on ultrafiltration parameters, fouling mechanisms and the pollutant removal efficiency on a model dairy wastewater.

*Correspondence: zsizsu@mk.u-szeged.hu 


\section{Experimental}

\subsection{Samples and Measurements}

Model solutions were prepared from milk powder (Milk Quick, Instantpack Kft., Hungary) composed of $0.3 \%$ $(\mathrm{g} / \mathrm{g})$ concentrations, 32\% $(\mathrm{g} / \mathrm{g})$ proteins, $5 \%(\mathrm{~g} / \mathrm{g})$ fat and $50 \%(\mathrm{~g} / \mathrm{g})$ lactose. Ozone was produced from oxygen (Linde, 3.0) with a flow-type ozone generator (Ozomatic Modular 4, Wedeco Ltd., Germany). The ozone-containing gas was bubbled continuously through a batch reactor during the treatment. The volume of the treated water was $0.45 \mathrm{dm}^{3}$. The durations of the treatment were 5, 10 and 20 mins; and the flow rate was 1 $\mathrm{dm}^{3} \mathrm{~min}^{-1}$. The ozone concentrations of the bubbling gas before and after it was passed through the batch reactor were measured with a ultraviolet-visible (UVVIS) spectrophotometer (Nanocolor NUV 0113) at a wavelength of $254 \mathrm{~nm}$ (Fig. 1). The absorbed ozone concentrations were $6.8 \cdot 10^{-4} \mathrm{M}, 1.43 \cdot 10^{-3} \mathrm{M}$ and $2.67 \cdot 10^{-3} \mathrm{M}$, respectively.

Fenton's reaction was conducted in a batch stirred ultrafiltration cell with $1.5 \mathrm{mmol} \mathrm{dm}{ }^{-3} \mathrm{FeSO}_{4} \times 7 \mathrm{H}_{2} \mathrm{O}$ (purity 99\%, Spektrum-3D, EU) adjusted to $\mathrm{pH} 3$ with $\mathrm{H}_{2} \mathrm{SO}_{4}$ (purity 96\%, Farmitalia Carlo Erba SPA, Italy), 0.3 wt. $\%$ milk powder solution and $\mathrm{H}_{2} \mathrm{O}_{2}$ solution $(30 \%$, purity $99 \%$, Spektrum-3D Kft.), the $\left[\mathrm{H}_{2} \mathrm{O}_{2}\right]$ :[Fe] ratio was $5: 1$ (Fenton $(5: 1)$ ) or 50:1 (Fenton $(50: 1)$ ). The ozone or Fenton pre-treated samples were used as a feed in ultrafiltration (UF) experiments.

The UF experiments were carried out in a batch stirred ultrafiltration cell (Millipore, Serial $N^{\circ} 94$, USA) with a capacity of $50 \mathrm{~cm}^{3}$, and the filtrations were performed at transmembrane pressures of 0.1 (only in the case of Fenton (50:1)) or $0.3 \mathrm{MPa}$ and the feed solutions were stirred at $350 \mathrm{rpm}$. For filtration experiments, flat sheet polyethersulfone (PES) membranes (PES-10 series, New Logic Research Inc., USA) and a molecular weight cut-off (MWCO) of $10 \mathrm{kDa}$ were used with an effective membrane surface area of $1.73 \mathrm{dm}^{2}$. The initial feed volume was $50 \mathrm{~cm}^{3}$, the ultrafiltration experiments were conducted until $40 \mathrm{~cm}^{3}$ of the total sample had been filtered, when the volume reduction ratio (VRR) was equal to 5 .

Determination of the COD was based on the standard method involving the oxidation of potassium dichromate; for the analysis, standard test tubes (Lovibond Tintometer Ltd.) were used. The digestions were conducted in a COD digester (Lovibond ET108 thermoreactor); and the COD values were measured with a COD photometer (Lovibond PCCheckit). For the determination of the residual amount of hydrogen peroxide, COD measurements were performed before and after the addition of the enzyme catalase.

\subsection{Theoretical Methodologies}

In order to investigate mechanisms of membrane fouling, filtration resistances were calculated according to the Resistance-In-Series Model, Eqs.(1-4).

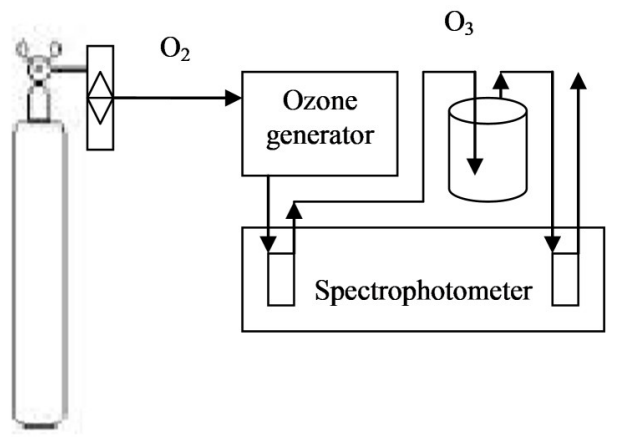

Figure 1. Experimental set-up of ozonation.

The membrane resistance $\left(R_{\mathrm{M}}, \mathrm{m}^{-1}\right)$ was calculated as

$$
R_{\mathrm{M}}=\frac{\Delta p}{J_{\mathrm{w}} \eta_{\mathrm{w}}}\left[\mathrm{m}^{-1}\right]
$$

where $\Delta p$ is the difference in pressure either side of the membrane (in $\mathrm{MPa}$ ), $J_{\mathrm{w}}$ is the water flux of the clean membrane, and $\eta_{w}$ is the viscosity of water (in $\mathrm{Pa} \cdot \mathrm{s}$ ).

The total resistance $\left(R_{\mathrm{T}}\right.$, in $\left.\mathrm{m}^{-1}\right)$, can be evaluated from the steady-state flux by using the Resistance-InSeries Model:

$$
R_{\mathrm{T}}=R_{\mathrm{M}}+R_{\text {irrev }}+R_{\text {rev }}
$$

where $R_{\text {irrev }}$ is the irreversible resistance (mainly caused by the fouled pores) and $R_{\mathrm{rev}}$ is the reversible resistance.

The irreversible resistance was determined by measuring the water flux through the membrane after filtration, rinsing it with deionized water to remove any particles of the residue layer from the surface, and subtracting the resistance of the clean membrane:

$$
R_{\text {irrev }}=\frac{\Delta p}{J_{\mathrm{WA}} \eta_{\mathrm{W}}}-R_{\mathrm{M}}
$$

where $J_{\mathrm{WA}}$ is the water flux after concentration tests. The reversible resistance of the layer deposited on the membrane surface was calculated as:

$$
R_{\mathrm{rev}}=\frac{\Delta p}{J_{\mathrm{C}} \eta_{\mathrm{W} \mathrm{W}}}-R_{\mathrm{irrev}}-R_{\mathrm{M}}
$$

where $J_{\mathrm{C}}$ is the constant flux at the end of the concentration test and $\eta_{\mathrm{ww}}$ is the viscosity of the wastewater viscosity [16].

Mathematical modelling of the fouling mechanism was studied based on the Hermia's model [17]. The Hermia's model describes the mechanism of membrane fouling based on blocking filtration laws, consisting of complete pore blocking, standard pore blocking and intermediate pore blocking, in addition to cake filtration (Table 1) to illustrate the different fouling mechanisms. 
Table 1. Hermia's filtration laws.

\begin{tabular}{|c|c|c|}
\hline $\begin{array}{l}\text { Fouling mecha- } \\
\text { nism }\end{array}$ & Filtration law & $\begin{array}{c}\text { Constant-pressure } \\
\text { filtration } \\
J_{0} A=\text { cont. }\end{array}$ \\
\hline $\begin{array}{l}\text { Complete pore } \\
\text { blocking }\end{array}$ & $J=J_{0} \mathrm{e}^{-\mathrm{kt}}$ & $\ln J=\ln J_{0}-\mathrm{k} t$ \\
\hline $\begin{array}{l}\text { Gradual pore } \\
\text { blocking (stand- } \\
\text { ard pore block- } \\
\text { ing) }\end{array}$ & $\begin{array}{l}J=J_{0} \cdot\left(1+1 / 2 K_{\mathrm{s}}\right. \\
\left.\left(\mathrm{A} \cdot J_{0}\right)^{1 / 2} \cdot t\right)^{-2}\end{array}$ & $\begin{array}{l}1 / J^{0.5}=1 / J_{0}^{0.5}+k_{\mathrm{s}} \cdot t \\
k_{\mathrm{s}}=0.5 K_{\mathrm{s}} A^{0.5}\end{array}$ \\
\hline $\begin{array}{l}\text { Intermediate } \\
\text { filtration }\end{array}$ & $\begin{array}{l}J=J_{0} \cdot(1+ \\
\left.K \cdot \mathrm{A} \cdot J_{0} \cdot t\right)^{-1}\end{array}$ & $\begin{array}{l}1 / J=1 / J_{0}+k_{\mathrm{i}} \cdot t \\
k_{\mathrm{i}}=K_{\mathrm{i}} A\end{array}$ \\
\hline Cake filtration & $\begin{array}{l}J=J_{0} \cdot(1 \\
\left.2 K_{\mathrm{c}}\left(\mathrm{A} \cdot J_{0}\right)^{2} \cdot t\right)^{-0.5}\end{array}+$ & $\begin{array}{l}l / J^{2}=1 / J_{0}^{2}+k_{\mathrm{c}} \cdot t \\
k_{\mathrm{c}}=2 K_{\mathrm{c}} A^{2}\end{array}$ \\
\hline
\end{tabular}

The Hermia's model was then linearized for each model using a fitting equation in terms of the permeate flux versus time as presented in Table 1. In terms of the evaluation of the results these models were fitted to experimental data. In Table $1, J$ is the flux, $J_{0}$ is the initial flux, the various $K$ 's are the fouling coefficients, and $A$ is a constant.

To compare the performance of different AOPs, the oxygen-equivalent chemical-oxidation capacity (OCC, $\mathrm{kg} \mathrm{O}_{2} \mathrm{~m}^{-3}$ ) was used to quantify the oxidants used in the ozone treatment and Fenton's reaction, and was determined based on stoichiometric calculations [14]:

$$
\mathrm{OCC}=1.000\left[\mathrm{O}_{3}\right]=0.471\left[\mathrm{H}_{2} \mathrm{O}_{2}\right]
$$

where $\left[\mathrm{O}_{3}\right]$ is the required ozone concentration $(\mathrm{kg} \mathrm{O}$ $\left.\mathrm{m}^{-3}\right)$, and $\left[\mathrm{H}_{2} \mathrm{O}_{2}\right]$ is the required hydrogen peroxide concentration $\left(\mathrm{kg} \mathrm{H}_{2} \mathrm{O}_{2} \mathrm{~m}^{-3}\right)$.

\section{Results and Analysis}

\subsection{Experiments}

The effect of pre-oxidation on filtration parameters was investigated by fitting equations in Table 1 to measured data. Based on the value of the coefficient of determination, the cake layer filtration yielded the best correlation. In order to compare the different pre-oxidation methods, normalised values of the initial flux $\left(J_{0}, \mathrm{~L} \mathrm{~m}^{-2}\right.$



Figure 2. Normalised initial flux values as a function of OCC.

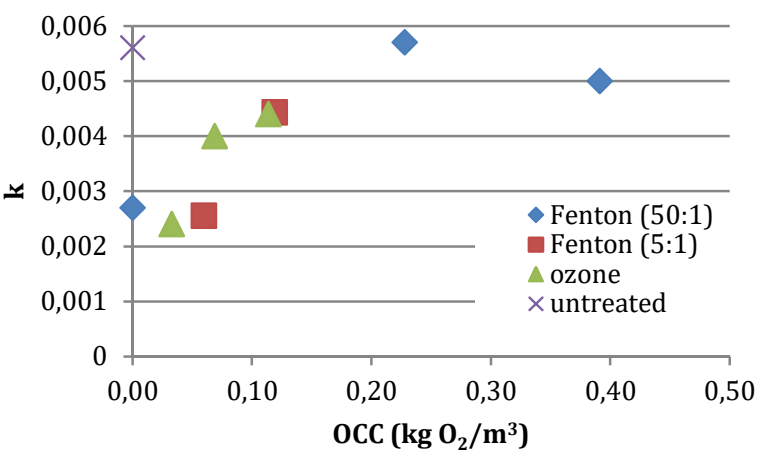

Figure 3. Fouling coefficient as a function of OCC.

$\mathrm{h}^{-1}$ bar $\left.^{-1}\right)$ and fouling coefficients $(k)$ were calculated and compared (Figs.2 and 3). It was found that the effect of ozone treatment and Fenton-treatment is different in the case of initial normalised flux. Not only the Fenton pre-treatment but the addition of reagents in the absence of hydrogen peroxide exhibited coagulationflocculation effects that resulted in an enhanced initial flux. In the case of the Fenton's reaction this effect is independent of the $\left[\mathrm{H}_{2} \mathrm{O}_{2}\right]:[\mathrm{Fe}]$ ratio.

The fouling coefficient also changes by the addition of oxidants, (Fig.3) but in this case, the tendency is more likely to depend on the OCC than on the applied AOP method. At lower oxidation capacities the fouling coefficient decreases resulting in lower degrees of fouling than in non-treated solutions, however, at higher oxidation grades, the fouling coefficient increases.

To obtain more information concerning the fouling mechanisms, the filtration resistances of ozone-treated and Fenton $(5: 1)$ pre-treated solutions were calculated and compared (Fig.4). It was found that - in accordance with the values of the fouling coefficient - filtration resistances decrease as the duration of oxidation pretreatment increases. In particular, mainly pre-treatments of short durations decreased the irreversible fouling resistance and increased the reversible fouling resistance.

\section{Discussion}

As an effect of the pre-oxidation of model dairy wastewater two typical pathways were observed that influence membrane filtration parameters: the i) micro-

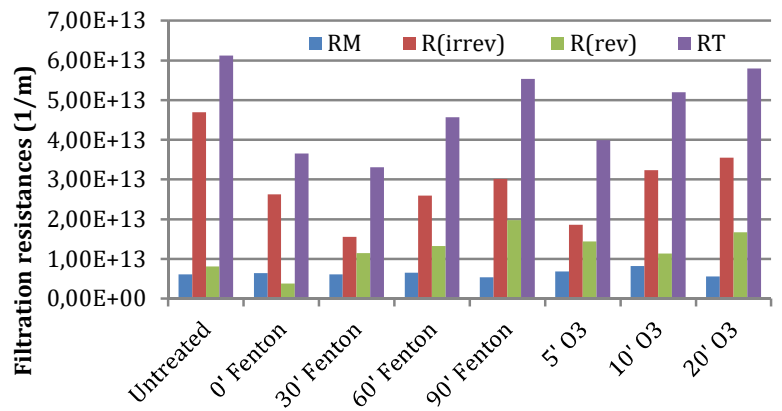

Figure 4. Filtration resistances of untreated, Fenton (5:1) and ozone pre-treated solutions. 


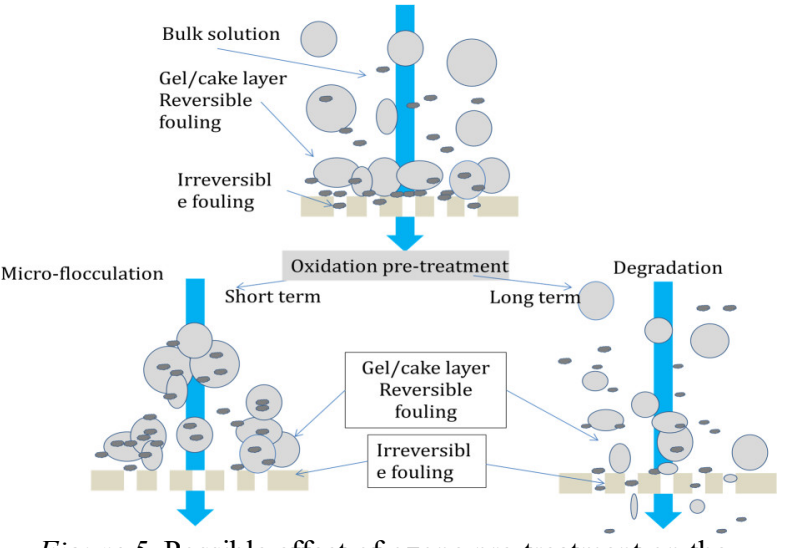

Figure 5. Possible effect of ozone pre-treatment on the membrane filtration of dairy wastewater.

flocculation effect produces associated colloidal particles, and ii) degradation of organic matter (Fig.5). The former resulted in decreased fouling of membrane pores as shown by the decreased fouling coefficient and irreversible resistance. This can be observed only during short-term ozone or Fenton treatments $(\mathrm{OCC}<0.05 \mathrm{~kg}$ $\mathrm{O}_{2} \mathrm{~m}^{-3}$ ). The latter point may increase the degree of pore fouling $[13,18]$ due to the formation of small degradation by-products, which can enter membrane pores as the increased values of irreversible resistance also prove. By comparing the ozone and Fenton pretreatment processes with similar OCCs, it can be concluded that the Fenton pre-treatment may be more effective in terms of enhancing the flux, probably due to the coagulation-flocculation effect of the ferrous salts themselves.

\section{Conclusion}

The comparison of ozone and Fenton processes as pretreatments before ultrafiltration of a model sample of dairy wastewater showed that such pre-treatments may improve the filtration parameters in terms of flux or fouling mitigation. By examining the effect of the oxidation capacities of ozone and Fenton pre-treatment processes, it was found that the fouling propensity of pollutants does not depend on the pre-treatment method. However, it depends on the OCC of the pre-treatment method. Although the method of pre-treatment affects the flux, the Fenton pre-treatment proved to be more efficient in terms of enhancing the value of the flux.

\section{SYMBOLS}

$\begin{array}{ll}R_{\mathrm{M}} & \text { membrane resistance }\left(\mathrm{m}^{-1}\right) \\ R_{\text {rev }} & \text { reversible resistance }\left(\mathrm{m}^{-1}\right) \\ R_{\text {irrev }} & \text { irreversible resistance }\left(\mathrm{m}^{-1}\right) \\ \Delta p & \begin{array}{l}\text { pressure difference between the two sides of } \\ \text { the membrane }(\mathrm{MPa})\end{array} \\ J & \text { flux }(1 / \mathrm{s}) \\ J_{\mathrm{W}} & \text { water flux }(1 / \mathrm{s}) \\ J_{\mathrm{C}} & \begin{array}{l}\text { constant flux at the end of the concentration } \\ (1 / \mathrm{s})\end{array} \\ J_{0} & \text { initial flux }(1 / \mathrm{s})\end{array}$

$\eta_{\mathrm{W}} \quad$ water viscosity $(\mathrm{Pa} \cdot \mathrm{s})$

$k \quad$ fouling coefficient

OCC oxygen-equivalent chemical-oxidation capacity $\left(\mathrm{kg} \mathrm{O}_{2} \cdot \mathrm{m}^{-3}\right)$

\section{Acknowledgement}

This research was supported by the János Bolyai Research Fellowship of the Hungarian Academy of Sciences. The authors are also grateful for the financial support of the National Research, Development and Innovation Office (NKFIH K1 12096).

\section{REFERENCES}

[1] Farizoglu, B.; Uzuner, S.: The investigation of dairy industry wastewater treatment in a biological high performance membrane system, Biochem. Eng. J., 2011 57, 46-54 DOI: 10.1016/j.bej.2011.08.007

[2] Vourch, M.; Balance, B.; Chaufer, B.; Dorange, G.: Treatment of dairy industry wastewater by reverse osmosis for water reuse, Desalination, 2008 219(1-3), 190-202 DOI 10.1016/j.desal.2007.05.013

[3] Perle, M.; Kimchie, S.; Shelef, G.: Some biochemical aspects of the anaerobic degradation of dairy wastewater, Water Res., 1995 29(6), 1549-1554 DOI 10.1016/0043-1354(94)00248-6

[4] Bick, A.; Plazas, T.J.G.; Yang, F.; Raveh, A.; Hagin, J.; Oron, G.: Immersed Membrane Bio Reactor (IMBR) for treatment of combined domestic and dairy wastewater in an isolated farm: An exploratory case study implementing the Facet Analysis (FA), Desalination, 2009 249(3), 12171222 DOI 10.1016/j.desal.2009.06.035

[5] Sarkar, B.; Chakrabarti, P.P.; Vijaykumar, A.; Kale, V.: Wastewater treatment in dairy industries: possibility of reuse, Desalination, 2006 195(1-3), 141-152 DOI 10.1016/j.desal.2005.11.015

[6] Andrade, L.H.; Motta, G.E.; Amaral, M.C.S.: Treatment of dairy wastewater with a membrane bioreactor, Braz. J. Chem. Engng., 2013 30(4), 759-770 DOI 10.1590/S0104-66322013000400008

[7] Yip, V.; Arntfield, S.D.; Hydamaka, A.W.: Potential for stainless steel microfiltration processing to reduce effluent from a fluid milk and ice-cream processing plant, J. Dairy Sci., 1996 79(4), 710-716 DOI 10.3168/jds.S0022-0302(96)76417-2

[8] Koyuncu, I.; Turan, M.; Topacik, D.; Ates, A.: Application of low pressure nanofiltration membranes, for the recovery and reuse of dairy industry effluents, Water Sci. Tech., 2000 41(1) 213-221 web: http://wst.iwaponline.com/content/41/1/213

[9] Luo, J.; Ding, L.; Qi, B.; Jaffrin, M.Y.; Wan, Y.: A two-stage ultrafiltration and nanofiltration process for recycling dairy wastewater, Bioresour. Technol., $2011 \quad$ 102(16), 7437-7442 DOI 10.1016/j.biortech.2011.05.012 
[10]Bégoin, L.; Rabiller-Baudry, M.; Chaufer, B.; Faille, C.; Blanpain-Avet, P.; Bénézech, T.; Doneva, T.: Methodology of analysis of a spiralwound module. Application to PES membrane for ultrafiltration of skimmed milk, Desalination, 2006 192(1-3), 40-53 DOI 10.1016/j.desal.2005.10.010

[11] Koutake, M.; Uchida, Y.; Sato, T.; Shimoda, K.; Watanabe, A.; Nakao, S.: Filtration membrane fouling in ultrafiltration of skim milk, 1: Causes and cleaning, J. Agric. Chem. Soc. Jpn., 1987 198, 677-681 web: http://agris.fao.org/agris-search/search.do? recordID=JP880163288

[12]Rabiller-Baudry, M.; Le Maux, M.; Chaufer, B.; Begoin, L.: Characterisation of cleaned and fouled membrane by ATR-FTIR and EDX analysis coupled with SEM: Application to UF of skimmed milk with a PES membrane, Desalination, 2002 146(1-3), 123-128 DOI 10.1016/S0011-9164(02)00503-9

[13]László, Zs.; Kertész, Sz.; Beszédes, S.; HovorkaHorváth, Zs.; Szabó, G.; Hodúr, C.: Effect of preozonation on the filterability of model dairy waste water in nanofiltration, Desalination, 2009 240(1-3), 170-177 DOI 10.1016/j.desal.2007.12.040
[14]Cańizares, P.; Paz, R.; Sáez, C.; Rodrigo, M.A.: Costs of the electrochemical oxidation of wastewaters: a comparison with ozonation and Fenton oxidation processes, J. Environ. Mgmt., 2009 90(1), 410-420 DOI 10.1016/j.jenvman.2007.10.010

[15] Özge, S.; Taner, Y.: Determination of the acute toxicities of physicochemical pretreatment and advanced oxidation processes applied to dairy effluents on activated sludge, American Dairy Science Association, J. Dairy Sci., 2015 98(4), 2337-2344 DOI 10.3168/jds.2014-8278

[16]Kertész, Sz.; László, Zs.; Forgács, E.; Szabó, G.; Hodúr, C.: Dairy waste-water purification by vibratory shear enhanced processing, Desalination Water Treat., 2012 37(1-3), 1-7 DOI $10.5004 /$ dwt.2011.2485

[17]Hermia, J.: Constant pressure blocking filtration law: Application to power law non-newtonian fluids, Trans. Ind. Chem. Eng., 1982 60(3), 183187 web: http://hdl.handle.net/2078.1/57489

[18]Zhu, H.T.; Wen, X.H.; Huang, X.: Pre-ozonation for dead-end microfiltration of the secondary effluent: suspended particles and membrane fouling, Desalination, 2008 231(1-3), 166-174 DOI 10.1016/j.desal.2007.11.044 